\title{
ANALISA PENGARUH PENAMBAHAN ZAT ADITIF ALAMI PADA BENSIN TERHADAP EMISI GAS BUANG UNTUK SEPEDA MOTOR 4 LANGKAH
}

\author{
Najamudin \\ Program Studi Teknik Mesin, Fakultas Teknik Universitas Bandar Lampung \\ Kampus A. Jl. Zainal Abidin Pagar Alam No. 26 Gedung E, Lt. 1 Bandar Lampung 35142 \\ Telp. (0721) 701979 \\ Email : najamudin@ubl.ac.id
}

\begin{abstract}
ABSTRAK
Dampak dari perkembangan teknologi otomotif mengakibatkan kebutuhan bahan bakar juga semakin meningkat. Dalam hal ini zat aditif digunakan untuk memberikan peningkatan sifat dasar dan nilai angka oktan tinggi untuk dapat meningkatkan kinerja mesin. Variabel penelitian meliputi variabel bebas yaitu prosentase campuran zat aditif dan premium sedangkan variabel terikat berupa emisi gas buang. Data yang diperoleh akan diplotkan pada grafik. dan akan dijadikan acuan untuk menilai besarnya pengaruh pemakaian zat aditif terhadap emisi gas buang yang dihasilkan. Dengan penambahan zat aditif akan memperbaiki proses pembakaran yang akan menurunkan kadar $\mathrm{CO}, \mathrm{CO} 2, \mathrm{HC}$, meningkatkan konsumsi oksigen $(\mathrm{O} 2)$ dan akan menghilangkan senyawa NOx. Dari hasil penelitian yang dilakukan di dapat bahwa penurunan senyawa emisi gas buang yang signifikan terjadi pada Kadar CO yang di hasilkan oleh bensin yang telah di campur zat aditif konsentrasi $(0.2 \mathrm{~g}: 100 \mathrm{ml})$ pada putaran $1.000 \mathrm{rpm}$ adalah $0.60 \%$ dengan penurunan sebesar $0.09 \%$. Nilai penurunan yang terjadi pada putaran $1.000 \mathrm{rpm}$ pembakaran menjadi lebih baik karena panas yang di hasilkan lebih stabil.
\end{abstract}

Kata kunci: Zat aditif, Mesin sepeda motor, Emisi gas buang

\begin{abstract}
The impact of the development of automotive technology resulted in increasing fuel demand. In this case additives are used to provide improved basic properties and high octane number values in order to improve engine performance. The research variables include the independent variable that is the percentage of additive and premium mixture while the dependent variable is the exhaust gas emission. The data obtained will be plotted on the graph. and will be used as a reference to assess the magnitude of the effect of the use of additives on exhaust emissions generated. With the addition of an additive will improve the combustion process which will reduce CO, $\mathrm{CO}$, $\mathrm{HC}$, increase oxygen consumption (O2) and will eliminate the NOx compound. From the results of research conducted in the can that the significant reduction of emissions of exhaust gas occurs in the CO concentration produced by gasoline that has been mixed additives concentration $(0.2 \mathrm{~g}: 100 \mathrm{ml})$ at 1,000 rpm rotation is $0.60 \%$ with a decrease of $0.09 \%$. The value of the decline that occurs in the round of 1,000 rpm of combustion becomes better because the heat generated is more stable.
\end{abstract}

Keywords: Additives, Motorcycle engines, Exhaust gas emissions

\section{PENDAHULUAN}

Tingkat polusi udara di indonesia semakin memprihatinkan. Dari semua penyebab polusi udara yang ada, emisi transportasi terbukti sebagai penyumbang pencemaran udara tertinggi di Indonesia, yakni sekitar $85 \%$ sebagaimana data yang dipaparkan oleh Pengkajian Ozon dan Polusi Udara Lembaga Penerbangan dan Antariksa Nasional (Lapan).
Hal ini diakibatkan oleh laju pertumbuhan kepemilikan kendaraan bermotor yang tinggi. Sebagian besar kendaraan bermotor itu menghasilkan emisi gas buang yang buruk, baik akibat perawatan yang kurang memadai ataupun dari penggunan bahan bakar dengan kualitas kurang baik misalnya kadar timbal yang tinggi.

Dalam hal ini akan dibahas lebih lanjut mengenai pemakaian zat aditif alami sebagai campuran bahan bakar kendaraan bermotor. Zat aditif alami ini berfungsi sebagai penghemat bahan

6 Najamudin; Analisa Pengaruh Penambahan Zat Aditif Alami Pada Bensin Terhadap Emisi Gas Buang Untuk Sepeda Motor 4 Langkah 
bakar, memperbaiki kinerja mesin, dan memperbaiki emisi gas buang penyebab terjadinya polusi. Untuk itu perlu dilakukan penelitian guna mengetahui pengaruh penggunaan zat aditif alami.

Tujuan dari penelitian ini adalah untuk mengetahui pengaruh penambahan zat aditif Naphthalene pada bahan bakar premium terhadap emisi gas buang pada mesin sepeda motor 4 langkah.

Agar pembahasan dari hasil yang yang didapat lebih terarah, maka dilakukan pengujiansebagai berikut :

- Pengujian dilakukan pada mesin bensin 4langkah dengan volume silinder $110 \mathrm{cc}$

- Penilaian mesin berdasarkan konsumsi bahan bakar dan emisi gas buang.

\section{Proses Pembakaran.}

Adalah reaksi kimia antara komponenkomponen bahan bakar (karbon dan hidrogen) dengan komponen udara (oksigen) yang berlangsung sangat cepat, yang membutuhkan panas awal untuk menghasilkan panas yang jauh lebih besar sehingga menaikkan suhu dan tekanan gas pembakaran. Elemen mampu bakar yang utama adalah karbon dan oksigen. Selama proses pembakaran, butiran minyak bahan bakar menjadi elemen komponennya, yaitu hidrogen dan karbon, akan bergabung dengan oksigen untuk membentuk air, dan karbon bergabung dengan oksigen menjadi karbon dioksida. Kalau tidak cukup tersedia oksigen, maka sebagian dari karbon, akan bergabung dengan oksigen menjadi karbon monoksida. Energi panas yang dilepaskan sebagai hasil proses pembakaran digunakan untuk menghasilkan daya motor bakar tersebut. bawah ini :

Reaksi pembakaran ideal dapat dilihat di

$$
\mathrm{C}_{8} \mathrm{H}_{18}+12,5\left(\mathrm{O}_{2}+3,773 \mathrm{~N}_{2}\right) \longrightarrow 8 \mathrm{CO}_{2}+9 \mathrm{H}_{2} \mathrm{O}+12,5\left(3,773 \mathrm{~N}_{2}\right)
$$

Dari reaksi di atas dapat dilihat bahwa N2 tidak ikut dalam reaksi pembakaran. Reaksi pembakaran di atas adalah reaksi pembakaran ideal.

\section{Bahan Bakar Bensin (Premium)}

Bahan bakar bensin didapat dari hasil penyulingan, dengan berat jenis dari 0,68 sampai 0,72 . Bensin merupakan campuran dari hasil-hasil penyulingan yang ringan dan paling berat berat jenisnya dan titik didih terakhir dari $190^{\circ} \mathrm{C}$. Bahan bakar bensin yang baik memiliki beberapa syarat utama yaitu:

1. Jernih, tidak berwarna, netral

2. Bebas dari belerang

3. Bebas dari endapan

4. Nilai pembakaran $10.000 \mathrm{kkal} / \mathrm{kg}$

5. Mempunyai sifat menyala yang baik.

6. Mempunyai ketahanan dentuman yang cukup (bilangan oktan 70).

\section{Emisi Gas Buang}

Udara adalah snatu campuran gas yang terdapat pada lapisan yang mengelilingi bumi. Komposisi campuran gas tersebut tidak selalu konstan. Komponen yang konsentrasinya paling bervariasi adalah air dalam bentuk uap $\mathrm{H}_{2} \mathrm{O}$ dan karbon diokside (CO2). Jumlah uap air yang terdapat diudara bervariasi tergantung dari cuaca dan suhu. Konsentrasi $\mathrm{CO}_{2}$ di udara selalu rendah, yaitu sekitar $0,03 \%$. Pengaruh proses-proses tersebut terhadap konsentrasi total $\mathrm{CO}_{2}$ diudara sangat kecil karena rendahnya konsentrasi $\mathrm{CO}_{2}$.

Tabel 3 Komposisi udara kering dan bersih

\begin{tabular}{|l|c|c|c|}
\hline \multicolumn{1}{|c|}{ Komponen } & Formula & Persen volume & Ppm \\
\hline Nitrogen & $\mathrm{N}_{2}$ & 78,08 & 780.800 \\
\hline Oksigen & $\mathrm{O}_{2}$ & 20,95 & 209.500 \\
\hline Argon & $\mathrm{Ar}$ & 0,934 & 9.340 \\
\hline Karbon diokside & $\mathrm{CO}_{2}$ & 0,0314 & 314 \\
\hline Neon & $\mathrm{Ne}$ & 0,00182 & 18 \\
\hline Helium & $\mathrm{He}$ & 0,000524 & 5 \\
\hline Metana & $\mathrm{CH}_{4}$ & 0,0002 & 2 \\
\hline Kripton & $\mathrm{Kr}$ & 0.000114 & 1 \\
\hline
\end{tabular}

Polutan udara primer, yaitu polutan yang mencangkup $90 \%$ dari jumlah polutan udara seluruhnya, dapat dibedakan menjadi lima kelompok sebagai berikut :

1. Karbon monokside (CO)

2. Nitrogen okside $\left(\mathrm{NO}_{\mathrm{X}}\right)$

3. Hidrokarbon(HC)

4. Sulfur diokside $\left(\mathrm{SO}_{\mathrm{X}}\right)$

5. Partikel

Sumber polusi yang utama berasal dari transportasi, di mana hampir $60 \%$ dari polutan yang dihasilkan terdiri dari karbon monokside dan sekitar $16 \%$ berasal dari hidrokarbon. Polutan yang paling utama adalah karbon monokside yang hampir mencapai setengahnya dari seluruh polutan udara yang ada.

\section{Karbon monokside}

Karbon monokside (CO) adalah suatu komponen tidak berwarna, tidak berbau dan tidak mempunyai rasa yang terdapat dalam bentuk gas pada suhu diatas $-192^{\circ} \mathrm{C}$. Komponen ini mempunyai berat sebesar 96,5\% dari berat air dan tidak larut dalam air. Karbon monokside yang terdapat di alam terbentuk dari salah satu proses sebagai berikut :

1. Pembakaran tidak lengkap terhadap karbon atau komponen yang mengandung karbon.

2. Reaksi antara karbon diokside dan komponen yang mengandung karbon pada suhu tinggi. 


\section{Hidrokarbon}

Sesuai dengan namanya, komponen hidrokarbon hanya terdiri dari elemen hidrogen dan karbon. Beribu-ribu komponen hidrokarbon terdapat di alam, dimana pada suhu kamar terdapat tiga bentuk yaitu gas, cair dan padat. Hidrokarbon yang banyak dihasilkan oleh manusia berasal dari transportasi, sedangkan sumber lainya misalnya dari pembakaran gas, minyak, arang dan kayu. Bensin yang merupakan suatu campuran kompleks antara hidrokarbonhidrokarbon sederhana dengan sejumlah kecil bahan tambahan nonhidrokarbon, bersifat segera menguap dan terlepas diudara. Pelepasan hidrokarbon dari kendaraan bermotor juga disebabkan oleh emisi minyak bakar yang belum terbakar di dalam buangan.

\section{Zat Aditif.}

Zat aditif merupakan bahan yang di tambahkan pada bahan bakar kendaraan bermotor, baik mesin bensin maupun mesin diesel. Zat aditif digunakan untuk memberikan peningkatan sifat dasar tertentu yang telah dimilikinya seperti aditif anti knocking untuk bahan bakar mesin bensin. Angka oktan bisa ditingkatkan dengan menambahkan zat aditif bensin. Juga untuk meningkatkan kemampuan bertahan terhadap terjadinya oksidasi pada pelumas. Zat aditif merupakan ikatan atom senyawa yang dicampur dalam bahan bakar untuk meningkatkan angka oktan. Kandungan kimia zat aditif akan beroksidasi dengan rantai ikatan atom bahan bakar untuk membentuk rantai ikatan atom yang lebih bercabang (Misalnya dengan menambahkan TEL (tetraethyl lead, $\mathrm{Pb}$ (C2H5)4 ), senyawa oksigenet, MTBE (Methyl Tertiary Buryl Ether, $\mathrm{C}_{5} \mathrm{H}_{\mathrm{n}} \mathrm{O}$ ), MMT Methylcyclopentadienyl Manganese Tricarbonly), etanol, dan naftalena.

\section{Zat Aditif yang digunakan (Naphtalene )}

Secara fisik, Naphtalene merupakan zat yang berbentuk keping kristal, mudah menguap dan menyublim serta tidak berwarna, umumnya berasal dari minyak bumi atau batu bara. Karena bentuk struktur kimia naphtalene serta sifat aromatik tersebut maka naphtalene seperti halnya benzene, mempunyai sifat anti-knocfdng yang baik. Oleh sebab itu penambahan naphtalene pada bensin akan meningkatkan mutu anti- knocking dari bensin tersebut).

a. Deskripsi Produk

Zat aditif ini $\mathrm{C} 10 \mathrm{H} 16 \mathrm{O}$, zat aditif bahan bakar ini berbentuk kamper. Bagus untuk mesin bensin dan diesel, larut yang mengandung naphthalene yang mampu meningkatkan nilai oktan dan membantu menghemat bahan bakar, meningkatkan tenaga dan mengurangi emisi. Naphtalene juga merupakan rangkaian hidrokarbon jenis aromatic, bahkan dapat juga disebut polyaromatik dengan struktur kimia berbentuk cincin benzena yang bersekutu dalam satu ikatan atau dua ordo lingkungan benzena dimana pada proses penggabungan tersebut kehilangan dua atom $\mathrm{C}$ dan empat atom $\mathrm{H}$ sehingga rumus kimianya menjadi CioHg. Secara fisik, Naphtalene merupakan zat yang berbentuk keping kristal, mudah menguap dan menyublim seria tidak berwarna, umumnya berasal dari minyak bumi atau batu bara. Karena bentuk struktur kimia naphtalene serta sifat aromatik tersebut maka naphtalene seperti halnya benzene, mempunyai sifat anti-knocfdng yang baik. Oleh sebab itu penambahan naphtalene pada bensin akan meningkatkan mutu anti- knocking dari bensin tersebut).

b. Keunggulan

- Menghemat penggunaan bahan bakar.

- Meningkatkan tenaga dan kualitas bahan bakar.

- Mengurangi emisi.

c. Kemasan : 1 bungkus ini memiliki berat $150 \mathrm{~g}$

\section{METODOLOGI PENELITIAN}

\section{Spesifikasi Sepeda Motor 4-langkah}

Tabel 4 Spesifikasi Sepeda Motor 4-langkah

\begin{tabular}{|c|c|}
\hline Tipe mesin & 4-angkah, SOHC \\
\hline Sistem pendingin & : Pendingingudara \\
\hline Jumlah silinder & $\therefore 1$ (satu) \\
\hline Kopling & Ganda, otomatis, sentrifugal tipe basah \\
\hline Stater & : Elektrik dan kick \\
\hline Diameter x Langkah & $: 50 \times 55,6 \mathrm{~mm}$ \\
\hline Kapasitas silinder & $: 109.1 \mathrm{ccc}(110 \mathrm{cc})$ \\
\hline Kompresi & $: 9,0: 1$ \\
\hline Gigi transmisi & :Rotary 4 Kecepatan (N-1-2.3-4.4) \\
\hline Aki & $: \mathrm{MF} 12 \mathrm{~V} \cdot 3 \mathrm{Ah}$ \\
\hline Kapasitas tangki bahan bakar & $: 3$, lititer \\
\hline Kapasitas oli & $: 0.8$ liter \\
\hline
\end{tabular}

\section{Alat yang di gunakan}

Berikut adalah alat-alat yang di gunakan selama penelitian beserta keterangannya :

\section{a. Stopwatch}

Stopwatch di gunakan untuk mengukur waktu pada saat pengujian. 
b. Gelas ukur $100 \mathrm{ml}$ Gelas ukur $100 \mathrm{ml}$ di gunakan untuk mengukur volume bahan bakar.

c. Perangkat analog

Dalam penelitian ini, speedometer dan odometer, sudah berada dalam satu unit panel analog motor pada dashboard. Speedometer dengan ketelitian $10 \mathrm{~km} / \mathrm{jam}$, odometer dengan ketelitian $100 \mathrm{~m}$.

d. Tangki bahan bakar buatan $150 \mathrm{ml}$

Di gunakan sebagai wadah bahan bakar ketika proses pengambilan data. Sehingga tidak menggunakan tangki bahan bakar motor agar lebih mudah dalam proses pengukuran konsumsi bahan bakar.

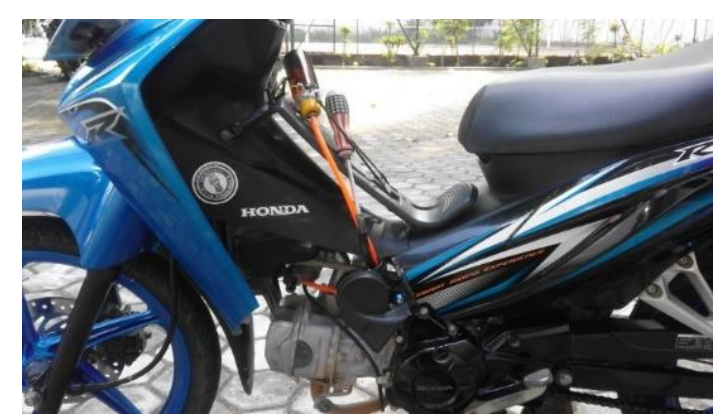

Gambar 1 Tangki bahan bakar buatan dan kawat pengait

e. Zat aditif

Zat aditif bahan bakar ini berbentuk kamper. Bagus untuk mesin bensin dan diesel, larut ini mengandung naphthalene yang mampu meningkatkan nilai oktan dan membantu menghemat bahan bakar, meningkatkan tenaga dan mengurangi emisi.

f. Fuel Gas Analyzer

Fuel gas analyzer di gunakan untuk mengukur gas buang hasil pembakaran.

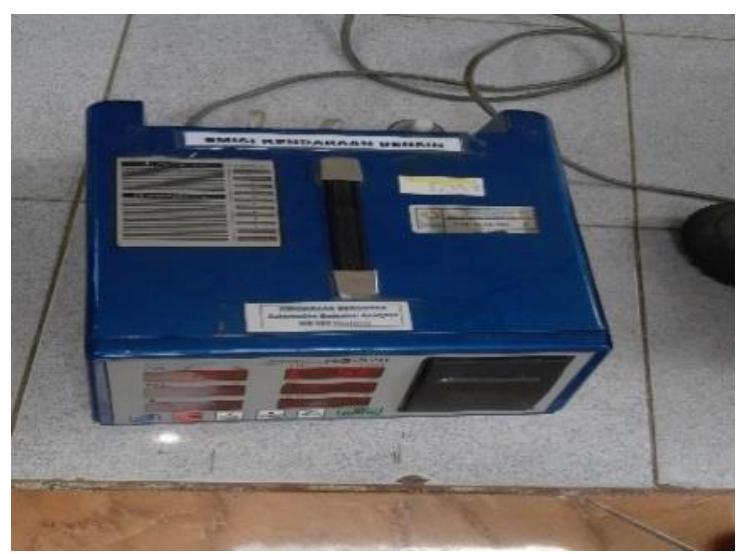

Gambar 2 Fuel gas analyzer HG-520 g. Kawat pengait dan selang bensin tambahan

Kawat pengait sebagai pengait tangki buatan ke rangka sepeda motor sedangkan selang tambahan untuk mengalirkan bensin dari tangki buatan kepada karburator.

\section{Prosedur Pengujian}

Awalnya mempersiapkan data aditif yang digunakan dan data kendaraan yang digunakan, setelah itu mempersiapkan alat uji dan alat ukur, dan selanjutnya pembersihan kendaraan seperti mesin ataupun karburator dibongkar terlebih dahulu untuk di lakukan pembersihan terhadap mesin dan karburator setelah itu oli mesin diganti dengan yang baru, begitu juga dengan businya.

\section{Pengujian Stasioner}

Pengujian ini di lakukan untuk melihat konsumsi bahan bakar dengan kondisi mesin diam atau tidak bergerak. Pada pengujian stasioner ini maka mesin dipanaskan terlebih dahulu sehingga didapatkan kinerja mesin yang optimal. Setelah itu putaran mesin yang dipakai adalah $1.000 \mathrm{rpm}$. Data yang diambil tiap pengujianya di lakukan pada cuaca dan lokasi pengujian yang hampir sama.

Pengujian di lakukan yaitu dengan menggunakan bensin yang telah diukur dengan menggunakan gelas ukur dan dituangkan pada tangki buatan yang telah dirancang sedemikian rupa sehingga memudahkan pengamatan. Pada pengujian pertama tanpa menggunakan zat aditif maka bensin yang telah ditakar tidak dicampur dengan zat aditif. Mesin dihidupkan dengan cara diengkol lalu stopwatch dihidupkan. Setelah 5 menit mesin dimatikan, kemudian bahan bakar tersisa diambil dari karburator dengan cara membuka baut pada dasar karburator dan diukur volume sisa dari bahan bakar tersebut dengan cara volume awal dikurangi volume akhir dari bahan bakar kemudjan dicatat. Untuk yang menggunakan zat aditif dengan konsentrasi yang berbeda-beda langkahnya sama dengan yang tidak menggunakan zat aditif. Pengukuran bertujuan untuk mengetahui konsumsi bahan bakar permenit. Adapun format tabel data pengujian stasioner.

\section{Pengujian Emisi Gas Buang}

Adapun tujuan pengujian emisi yaitu untuk mengetahui adanya pengaruh penggunaan zat aditif terhadap emisi gas buang. Berikut ini skema pengujian emisi gas buang pada sepeda motor:

9 Najamudin; Analisa Pengaruh Penambahan Zat Aditif Alami Pada Bensin Terhadap Emisi Gas Buang Untuk Sepeda Motor 4 Langkah 


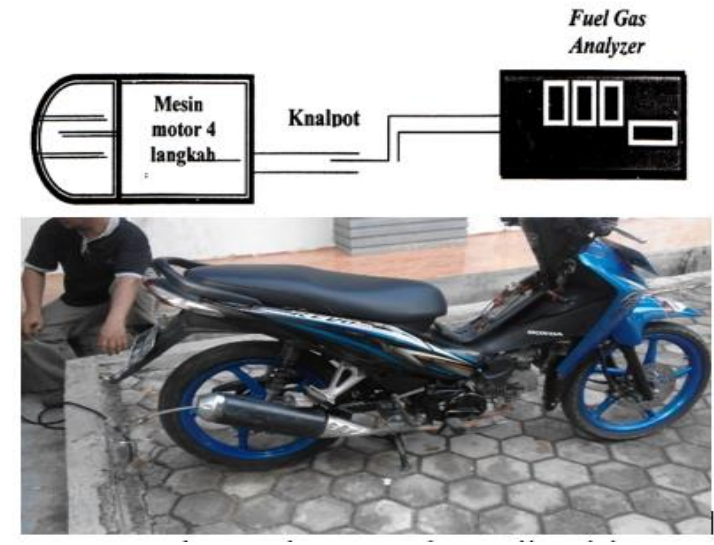

Gambar 3 Skema peralatan uji emisi

Pengujian emisi di lakukan pada kondisi stasioner dengan prosedur sebagai berikut :

1. Pemanasan mesin

Pemanasan mesin di lakukan untuk mempersiapkan mesin pada kondisi kerja sehingga dapat di gunakan.

2. Kalibrasi gas analyzer

Kalibrasi ini di lakukan secara otomatis setetah tombol ON pada gas analyzer ditekan. Dengan posisi sensor sudah berada pada saluran buang dan nilai-nilai kadar gas buang mulai terbaca pada display gas analyzer. Di lakukan setelah mesin dalam kondisi kerja.

3. Pengujian tanpa menggunakan zat aditif

Data yang didapatkan dari hasil pengukuran ini di gunakan sebagai pembanding dengan data pada pengukuran menggunakan zat aditif.

Langkah-langkah pengukuran sebagai berikut:

a. Mesin dalam keadaan menyala dalam kondisi idle $1.000 \mathrm{rpm}$ dan probe sensor sudah dimasukkan dalam knalpot.

b. Nilai pada fuel gas analyzer diprint datanya setelah 5 menit motor dihidupkan.

4. Pengujian menggunakan zat aditif.

Pengujian menggunakan zat aditif ini hanya dipilih dari performa pengujian stasioner, yang terbaik. Adapun langkah-Iangkah yang di gunakan adalah sebagai berikut :

a. Setelah mesin dimatikan kemudian zat aditif dimasukkan kedalam tangki bahan bakar yang telah berisi bensin.

b. Setelah itu, mesin dihidupkan kembali lalu pengukuran diulang kembali sesuai urutan pengukuran pertama.

\section{ANALISA DAN PEMBAHASAN}

Setelah melakukan pengujian mengenai pengaruh penambahan zat aditif terhadap prestasi, emisi gas buang pada mesin sepeda motor 4-langkah maka di peroleh data dari pengujian yang terdiri dari data mengenai, konsumsi bahan bakar, dan emisi gas buang.

\section{Pengambilan data untuk Konsentrasi terbaik \\ Tabel 5 Data pengujian dan pengambilan konsentrasi terbaik.}

\begin{tabular}{|c|c|c|c|c|c|}
\hline \multirow{2}{*}{ No } & \multirow{2}{*}{ Bahan Bakar } & \multicolumn{3}{|c|}{ Kadar } & \multirow{7}{*}{$\begin{array}{l}\text { Peraturan Menteri Negara } \\
\text { Lingkungan Hidup No. } 05 \\
\text { tahun 2006. Tentang Ambang } \\
\text { Batas Emisi Kendaraan } \\
\text { Bermotor Lama. }\end{array}$} \\
\hline & & $\begin{array}{l}\mathrm{CO} \\
(\%)\end{array}$ & $\begin{array}{c}\mathrm{HC} \\
(\mathrm{ppm})\end{array}$ & $\begin{array}{l}\mathrm{CO} 2 \\
(\%)\end{array}$ & \\
\hline 1 & Bensin & $0.69 \%$ & $852 \mathrm{ppm}$ & $25 \%$ & \\
\hline 2 & $\begin{array}{l}\text { Aditif + bensin } \\
(0.05 \mathrm{~g} / 100 \mathrm{ml})\end{array}$ & $0.69 \%$ & $852 \mathrm{ppm}$ & $25 \%$ & \\
\hline 3 & $\begin{array}{l}\text { Aditif }+ \text { bensin } \\
(0.1 \mathrm{~g} / 100 \mathrm{ml})\end{array}$ & $0.67 \%$ & $852 \mathrm{ppm}$ & $25 \%$ & \\
\hline 4 & $\begin{array}{l}\text { Aditif + bensin } \\
(0: 2 \mathrm{~g} / 100 \mathrm{ml})\end{array}$ & $0.60 \%$ & $822 \mathrm{ppm}$ & $25 \%$ & \\
\hline 5 & Standar Mutu & $4.5 \%$ & $2000 \mathrm{ppm}$ & - & \\
\hline
\end{tabular}

Dari semua pengujian tersebut maka dapat diketahui bahwa nilai dan konsentrasi terbaik adalah $(0: 2 \mathrm{~g} / 100 \mathrm{ml})$ karena hasil data lebih baik dari pada $(0.05 \mathrm{~g} / 100 \mathrm{ml})$ dan $(0.1 \mathrm{~g} / 100 \mathrm{ml})$. selain itu kadar CO dan HC dari $(0.05 \mathrm{~g} / 100 \mathrm{ml})$ dan $(0.1 \mathrm{~g} /$ $100 \mathrm{ml}$ ) lebih tinggi dan tidak ada perubahan seperti tidak ada reaksi aditif.

Maka dengan itu data yang dapat dipakai adalah konsentrasi terbaik yaitu $(0: 2 \mathrm{~g} / 100 \mathrm{ml})$.

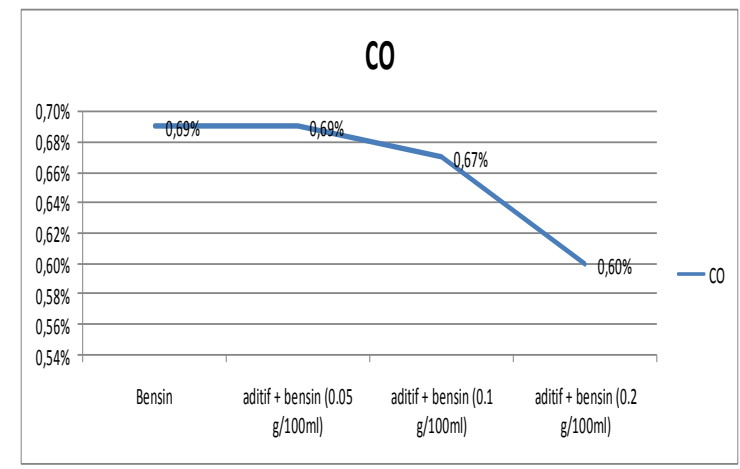

Gambar 4 Grafik pengaruh perbandingan antara bensin dan konsentrasi zat aditif terhadap gas CO.

10 Najamudin; Analisa Pengaruh Penambahan Zat Aditif Alami Pada Bensin Terhadap Emisi Gas Buang Untuk Sepeda Motor 4 Langkah 


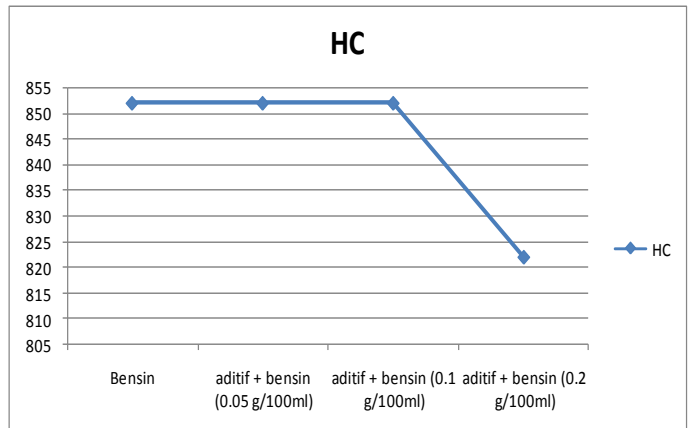

Gambar 5 Grafik pengaruh perbandingan antara bensin dan konsentrasi zat aditif terhadap gas HC.

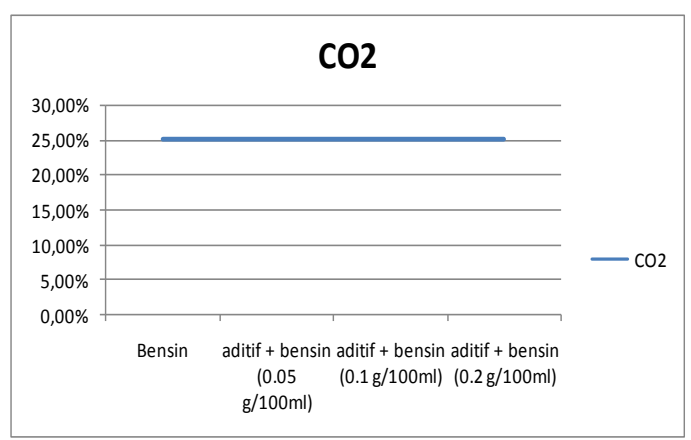

Gambar 6 Grafik pengaruh perbandingan antara bensin dan konsentrasi zat aditif terhadap gas $\mathrm{CO2}$

\section{Pengujian Stasioner}

Pengujian Stasioner merupakan pengujian yang di lakukan dalam keadaan diam tanpa beban. Jadi mesin dihidupkan pada putaran $1.000 \mathrm{rpm}$ dalam keadaan diam dan dihidupkan selama 5 menit. Pengujian ini bertujuan untuk mendapatkan nilai konsumsi bahan bakar dalam keadaan Stasioner. Kondisi dalam pengujian diusahakan hampir sama dengan keadaan dan waktu yang sama.

\section{Pengujian Stasioner 1.000 rpm}

Pengujian Stasioner di lakukan dengan tujuan mengetahui konsumsi bahan bakar pada kondisi Stasioner pada $1.000 \mathrm{rpm}$ dengan waktu pengujian 5 menit. Adapun hasil yang didapat adalah sebagai berikut:

a. Bensin Murni tanpa zat aditif. Pada pengujian tanpa menggunakan zat aditif pada putaran 1000 rpm dengan waktu 5 menit di peroleh konsumsi bahan bakar awal adalah $50 \mathrm{ml}$ bensin dan setelah itu karburator dibongkar dan melakukan pengukuran sisa bahan bakar bensin dan sisa bahan bakar sebesar $3.0 \mathrm{ml}$.

b. Setelah penambahan zat aditif terhadap bensin maka nilai dari konsumsi bahan bakar menurun.
Hal ini dikarenakan dengan penambahan zat aditif alami terhadap bensin maka kualitas bahan bakar menjadi lebih baik, diperoleh data sebagai berikut putaran $1000 \mathrm{rpm}$ dalam waktu 5 menit dengan volume awal $50 \mathrm{ml}$ bensin dan aditif 0.2 $\mathrm{g}$ setelah itu melakukan pembongkaran karburator dan pengukuran sisa bahan bakar diperoleh sebesar $3.9 \mathrm{ml}$, mengalami penurunan yang besar dan memiliki selisi $0.9 \mathrm{ml}$.

\section{Perbandingan Konsumsi Bahan Bakar Pada Setiap Pengujian}

Konsumsi bahan bakar merupakan salah satu parameter prestasi mesin yang sangat penting, karena jika konsumsi bahan bakar yang digunakan semakin sedikit maka dapat dikatakan bahwa kendaraan tersebut irit bahan bakar dan tentunya hal demikian itu sangat dibutuhkan oleh masyarakat Berikut ini dalam tabel 5 akan ditampilkan banyaknya konsumsi bahan bakar yang dibutuhkan dalam setiap pengujian dengan variasi konsentrasi zat aditif alami.

Tabel 6 Data pengaruh bahan bakar tanpa zat aditif dan menggunakan zat aditif :

\begin{tabular}{|c|c|c|c|c|c|c|c|c|}
\hline No & Bahan bakar & $\begin{array}{c}\text { Putaran } \\
(\text { Rpm })\end{array}$ & Waktu & $\begin{array}{c}\text { Volume } \\
\text { Awal }\end{array}$ & $\begin{array}{c}\text { Volume } \\
\text { Althir }\end{array}$ & V awal $-\mathrm{v}$ akhir & $\begin{array}{c}\text { Persentase } \\
(\%)\end{array}$ & Selisih \\
\hline 1 & Bensin & $1000 \mathrm{rmm}$ & $5 \mathrm{menit}$ & $50 \mathrm{ml}$ & $3.0 \mathrm{ml}$ & $50-3.0=47.0 \mathrm{ml}$ & $0.94 \%$ & $\begin{array}{c}0.9 \mathrm{ml} \\
\text { ataupun } \\
\text { sama } \\
\text { dengan } \\
0.018 \%\end{array}$ \\
\hline 2 & $\begin{array}{c}\text { Aditif }+ \text { bensin } \\
(0.2 \mathrm{~g}+50 \mathrm{ml})\end{array}$ & $1000 \mathrm{rpm}$ & 5 menit & $50 \mathrm{ml}$ & $3.9 \mathrm{ml}$ & $50-3.9=46.1 \mathrm{ml}$ & $0.922 \%$ & \\
\hline
\end{tabular}

Pada tabel di atas dapat diketahui bahwa dengan penambahan zat aditif terhadap bensin dapat menurunkan konsumsi bahan bakar yang diperlukan. Konsumsi untuk bahan bakar yang dibutuhkan pada pengujian adalah konsentrasi $(0.2 \mathrm{~g}: 100 \mathrm{ml})$ merupakan konsumsi terbaik. Penjelasan lebih lanjut untuk konsumsi bahan bakar telah di jelaskan pada bagian halaman sebelumnya. Dengan demikian, penambahan zat aditif alami terhadap bensin dapat menurunkan konsumsi bahan bakar yang digunakan.

\section{Pengujian Emisi}

Pengujian emisi ini bertujuan untuk mengetahui komposisi emisi gas buang yang di hasilkan yang meliputi kadar $\mathrm{CO}, \mathrm{HC}$, dan $\mathrm{CO} 2$ yang terdapat pada bensin tanpa zat aditif dan campuran bensin dengan zat aditif yang dipilih memiliki prestasi konsumsi bahan bakar yang baik. Pengujian ini di lakukan dengan putaran $1.000 \mathrm{rpm}$

\section{Gas CO}

Dari hasil pengujian bahwa pada putaran 1.000 rpm kadar CO yang di hasilkan bensin tanpa pencampuran zat aditif alami adalah $0.69 \%$. dengan Jumlah ini masih dibawah standar keamanan dari 
Menteri Negara Lingkungan Hidup yaitu yang tertuang dalam peraturan Menteri Lingkungan Hidup Nomor 5 tahun 2006 tentang ambang batas emisi gas buang kendaraan bermotor lama yang mana kadar CO minimal yang di hasilkan dari kendaraan 4 langkah dengan tahun pembuatan di bawah 2010 adalah 4,5\%. Akan tetapi dengan penambahan zat aditif alami tentunya kadar CO dapat diminimalisir lagi.

Kadar CO yang di hasilkan oleh bensin yang telah di campur zat aditif konsentrasi $(0.2 \mathrm{~g}: 100 \mathrm{ml})$ pada putaran $1.000 \mathrm{rpm}$ adalah $0.60 \%$ dengan penurunan sebesar $0.09 \%$. Nilai penurunan yang terjadi pada putaran $1.000 \mathrm{rpm}$ pembakaran menjadi lebih baik karena panas yang di hasilkan lebih stabil. Adanya penurunan nilai dari emisi gas $\mathrm{CO}$ ini menunjukkan bahwa dengan penambahan zat aditif alami dapast menaikkan kualitas pembakaran dan menurunkan emisi.

\section{Gas HC}

Dari hasil pengujian di atas dapat diketahui kadar HC yang di hasilkan untuk bensin tanpa campuran zat aditif adalah sebesar 852 ppm untuk putaran $1.000 \mathrm{rpm}$. Setelah di campur zat aditif alami dengan konsentrasi $(0.2 \mathrm{~g}: 100 \mathrm{ml})$ maka didapatkan penurunan kadar HC. Pada putaran $1.000 \mathrm{rpm}$, zat aditif alami dengan konsentrasi $(0.2 \mathrm{~g}: 100 \mathrm{ml})$ ini menghasilkan kadar HC sebesar 822 ppm dan pada putaran $1.000 \mathrm{rpm}$. Akan tetapi terbukti dengan penambahan zat aditif alami dapat menurunkan kadar HC.

Kadar HC yang di hasilkan pada putaran $1.000 \mathrm{rpm}$, menghasilkan kadar HC yang rendah ini karenan semakin tinggi putaran mesin maka pembakaran cepat terjadi dan rnesin menjadi lebih panas dan bahan bakar yang tidak terbakar menjadi lebih banyak terbakar karena lebih panas sehingga pembakaran menjadi lebih sempurna. HC ini terbentuk karena pada akhir pembakaran terdapat bahan bakar yang tidak terbakar menempel pada dinding silinder yang menuju katup buang, sehingga sebagian kecil dari HC yang tidak terbakar tersebut meninggalkan silinder melalui katup buang dan menuju ke lingkungan melalui kenalpot. Jumlah dari pada HC ini tergantung dari suhu gas, komposisi pembakaran dan waktu tinggal HC pada dinding silinder. Jadi semakin cepat putaran piston dapat dipastikan suhu semakin meningkat, pembakaran lebih sempurna dan waktu tingga) HC pada dinding silinder semakin sebentar ini mengakibatkan kandungan $\mathrm{HC}$ semakin sedikit.

\section{Gas $\mathrm{CO}_{2}$}

Gas $\mathrm{CO}_{2}$ merupakan gas dari hasil pembakaran atau bisa dikatakan sebagai produk dari pembakaran. Semakin tinggi kadar $\mathrm{CO}_{2}$ yang di hasilkan maka pembakaran yang terjadi semakin sempurna. Sebaliknya jika kadar $\mathrm{CO}_{2}$ yang di hasilkan semakin rendah maka pembakaran tersebut kurang sempurna Hal ini sama dengan seperti gambar 20 bahwa kadar $\mathrm{CO}_{2}$ sebesar $2.5 \%$ pada putaran 1.000 rpm. Sama dengan zat aditif dengan konsentrasi $(0.2$ $\mathrm{g}: 100 \mathrm{ml}$ ) menghasilkan kadar $\mathrm{CO}_{2}$ sebesar 2,5\% pada putaran $1.000 \mathrm{rpm}$. Jadi dapat disimpulkan bahwa pembakaran yang dihasilkan sama.

Tabel 7 Data pengujian emisi gas buang sepeda motor 4-langkah dengan putaran 1.000 rpm.

\begin{tabular}{|c|c|c|c|c|c|}
\hline No. & Bahan Bakar & $\begin{array}{c}\text { Putaran Mesin } \\
(\mathrm{rpm})\end{array}$ & $\begin{array}{c}\text { Kadar CO, } \\
(\%)\end{array}$ & $\begin{array}{c}\text { Kadar HC, } \\
(\mathrm{ppm})\end{array}$ & $\begin{array}{c}\text { Kadar } \\
\mathrm{C0}_{2}(\%)\end{array}$ \\
\hline 1 & Bensin & $1000 \mathrm{rpm}$ & $0.69 \%$ & $852 \mathrm{ppm}$ & $2.5 \%$ \\
\hline 2 & $\begin{array}{c}\text { Aditif+ } \\
\text { bensin(0.2g:100ml) } \\
\text { (Prestasi terbaik) }\end{array}$ & $1000 \mathrm{rpm}$ & $0.60 \%$ & $822 \mathrm{ppm}$ & $2.5 \%$ \\
\hline
\end{tabular}

Tabel 8 Data pengujian emisi gas buang sepeda motor 4-langkah dengan putaran $1.000 \mathrm{rpm}$.

\begin{tabular}{|c|c|c|c|c|c|}
\hline No. & Bahan Bakar & $\begin{array}{c}\text { Putaran Mesin } \\
\text { (rpm) }\end{array}$ & $\begin{array}{c}\text { Kadar CO, } \\
(\%)\end{array}$ & $\begin{array}{c}\text { Kadar HC, } \\
(\mathrm{ppm})\end{array}$ & \multirow{4}{*}{$\begin{array}{l}\text { Peraturan Menteri } \\
\text { Negara Lingkungan } \\
\text { Hidup No. } 05 \text { tahun } \\
\text { 2006. } \\
\text { Tentang Ambang Batas } \\
\text { Emisi Kendaraan } \\
\text { Bermotor Lama. }\end{array}$} \\
\hline 1 & Bensin & $1000 \mathrm{rpm}$ & $0.69 \%$ & $852 \mathrm{ppm}$ & \\
\hline 2 & $\begin{array}{c}\text { Aditif }+ \\
\text { bensin( } 0.2 \mathrm{~g}: 100 \mathrm{ml}) \\
\text { (Prestasi terbaik) }\end{array}$ & $1000 \mathrm{rpm}$ & $0.60 \%$ & $822 \mathrm{ppm}$ & \\
\hline 3 & Standar Mutu & - & $4.5 \%$ & $2000 \mathrm{ppm}$ & \\
\hline
\end{tabular}

\section{KESIMPULAN}

Berdasarkan hasil pengujian dan pembahasan yang telah dilakukan maka di dapat kesimpulan sebagai berikut:

1. Pengujian konsumsi bahan bakar stasioner pada $1.000 \mathrm{rpm}$ selama 5 menit di dapat prestasi terbaik pada konsentrasi $(0.2 \mathrm{~g}$ aditif $/ 100 \mathrm{ml}$ bensin) yaitu sebesar $0.94 \%$ bensin dan $0.922 \%$ bensin+aditif jadi selisih $0.9 \mathrm{ml}=0.018 \%$ dari kesimpulan tersebut diketahui bahwah aditif + bensin dapat menurunkan konsumsi bahan bakar.

2. Emisi gas buang yang dihasilkan dalam proses pembakaran dapat direduksi dengan penambahan zat aditif alami konsentrasi $(0.2 \mathrm{gr}$ aditif /100 ml terhadap bensin.

3. Kadar CO dapat diturunkan sebesar $0.09 \%$ $0.14 \%$ pada putaran $1.000 \mathrm{rpm}$ pada konsentrasi (0.2 g aditif / $100 \mathrm{ml}$ bensin)

4. Penurunan kadar HC yang dihasilkan dari proses pembakaran pada putaran $1.000 \mathrm{rpm}$ adalah 813 - 822 ppm pada konsentrasi ( $0.2 \mathrm{~g}$ aditif / $100 \mathrm{ml}$ bensin. Penambahan zat aditif alami pada bahan bakar dapat menghasilkan pembakaran 
yang lebih sempurna terbukti dengan kadar $\mathrm{CO}_{2}$ pada putaran $1.000 \mathrm{rpm}$ yaitu $2.5 \%$. dan kadar $\mathrm{O}_{2}$ masing-masing sebesar $11.20 \%-13.44 \%$ dibandingkan dengan bensin tanpa aditif yaitu $12,05 \%$ dan $15.24 \%$ pada konsentrasi $(0.2 \mathrm{~g}$ aditif/100 $\mathrm{ml}$ bensin).

\section{DAFTAR PUSTAKA}

[1] [Arismunandar, W. 1983. Penggerak Mula Motor Bakar Torak. ITB. Bandung.

[2] Tirtoatmodjo, R. 2001. Pengaruh Naphtalene Terhadap Perubahan Angka Oktan Bensin, Unjuk Kerja Motor dan Gas Buangnya. Jurusan Teknik Mesin-Universitas Kristen Petra.

[3] Arends.BPM dan Berenschot.H, 1980"Motor Bensin", Erlangga, Jakarta

[4] Daryanto, 1996. Mesin Perkakas Bengkel”, PT. Rineka Cipta, Cetakan ketiga, Jakarta

[5] Kusnandar, Iwan 2011, "Pengaruh Penambahan Mygreenoil Dalam Premium Terhadap Emisi
Gas Buang Karbon Monoksida (Co) Pada Sepeda Motor Honda Supra X Tahun 2004”, Other Thesis, Universitas Sebelas Maret. Surakarta.

[6] Marsudi. Ir, 1979, “Motor Bakar 3”, Edisi ketiga, Jakarta.

[7] Werlin S nainggolan, 1987, "Thermodinamika", Cv. Armico, Bandung.

[8] Williar W.Pulkrabek, 2002 "Engineering Fundamentals of The Internal Combustion Engine”, Pearson Prentice Hall, Second edition.

[9] Zevy D. Maran, 2007, "Peralatan Bengkel Otomotif", CV. Andi Offset, Yogyakarta.

[10]Wahyu Eko Saputra, Harmen Burhanuddin, M.Dyan Susila, 2013, "Pengaruh Penambahan Zat Aditif Alami Pada Bensin Terhadap Prestasi Sepeda Motor 4-Langkah", JURNAL FEMA, Jurnal Ilmiah Teknik Mesin, Volume 1, Nomor 1, Januari 2013, Universitas Lampung, Bandar Lampung. 